\title{
FEODALISME DALAM NOVEL PIPISAHAN KARYA RAF
}

\author{
FEUDALISM IN RAF'S PIPISAHAN
}

\author{
Resti Nurfaidah \\ Balai Bahasa Provinsi Jawa Barat \\ Jalan Sumbawa Nomor 11 Bandung 40113 \\ e-mail: goresan_penaku@yahoo.com dan sineneng1973@gmail.com
}

Naskah Diterima: 7 Januari $2015 \quad$ Naskah Direvisi:13 Februari $2015 \quad$ Naskah Disetujui:23 Februari 2015

\begin{abstract}
Abstrak
Feodalisme muncul pada abad pertengahan sebagai dampak dari implementasi sistem vassal. Feodalisme tidak pernah hilang bahkan setelah era imperialisme telah berakhir. Sistem politik dan sosial yang sangat membanggakan hirarki manusia tersebut selalu hadir dalam kehidupan manusia, terutama di tempat-tempat yang masih mengadopsi sistem tuan tanah. Dampak terbesar dari feodalisme adalah penghancuran nilai-nilai kemanusiaan dengan timbulnya diskriminasi yang tidak didasarkan pada prestasi seseorang, tetapi pada posisi dan kekuasaan seseorang. Kajian ini mendapati bahwa dalam novel berjudul Pipisahan, feodalisme menjadi pencetus timbulnya kelompok marginal dalam kehidupan masyarakat, terutama di lingkungan terkecil seperti keluarga. Dalam kajian tersebut, feodalisme terdapat dalam korpus berupa tuturan dan perilaku tokoh bapak mertua terhadap anak dan menantunya. Korpus tersebut dikaji berdasarkan pada konsep feodalisme berikut, antara lain, feodalisme Simorangkir, Reeser, dan Connell. Sementara itu, sisi maskulinitas dikaji berdasarkan konsep Humm sementara konsep tentang meme dilandasi pandangan Dawskins.
\end{abstract}

Kata kunci: feodalisme, novel Sunda.

\begin{abstract}
Feudalism emerged in the middle ages as a result of the implementation of vassal system. Feudalism never disappear even after the era of imperialism has ended. Political and social system which is very proud of the human hierarchy is present in human life, especially in places that are still adopting the landlord system. The biggest impact of feudalism is destruction of human values with the incidence of discrimination which is not based on individual achievement, but on one's position and power. This study found that in the novel entitled Pipisahan, feudalism trigger the onset of marginalized groups in public life, especially in the smallest environments like family. In this study, feudalism contained in the corpus in the form of speech and behavior of the father figures of children and daughter-in-law. The corpus studied based on the concept of feudalism as follow; feudalism Simorangkir, Reeser, and Connell. Meanwhile, the concept of masculinity assessed based Humm, while the concept of the meme is based on Dawskins.
\end{abstract}

Keywords: feudalism, Sundanese novel.

\section{A. PENDAHULUAN}

Kajian ini mengeksplorasi aspek feodalisme dalam kehidupan manusia. Hal itu dilandasi oleh sisi keabadian Feodalisme, yang muncul sejak abad pertengahan, selalu bertahan. Tema feodalisme telah banyak diteliti karena hal itu menyebabkan perubahan nasib manusia, antara lain perbedaan pada status sosial atau persamaan ideologi tertentu, 
bahkan, perseteruan hingga kematian. Feodalisme merupakan sistem kekuasaan yang memberikan keuntungan pada pihak yang berkuasa (bangsawan) dan merugikan pihak yang tertindas (rakyat jelata). Sistem tersebut berlangsung secara turun-temurun dan masih diberlakukan hingga tiba pada era kehidupan modern. Pihak yang diuntungkan oleh feodalisme tidak begitu saja mau melepaskan sistem yang sudah lama dianutnya itu, meskipun sistem tersebut menimbulkan efek yang kurang baik bagi pihak yang tertindas.

Kontak jangka panjang kaum bangsawan Indonesia dengan kaum penjajah mengubah cara pandang mereka terhadap kehidupan keseharian. Interaksi tersebut menimbulkan berbagai bentuk produk budaya berbasis feodalisme yang membakukan sebagai petinggi dan memisahkan mereka dari rakyat kebanyakan. Di antara produk budaya berbasis feodalisme tersebut antara lain, tata cara atau etika pergaulan dan hirarki bahasa yang membuka jurang perbedaan antara rakyat kebanyakan, kaum menengah dan atas. Selain itu, feodalisme tersebut terbawa ke dalam karya sastra yang diproduksi saat itu. Karya sastra yang muncul sebagai hasil interaksi antara kalangan bangsawan dan kaum penjajah, mau tidak mau mengusung pengaruh yang luar biasa dalam dunia sastra negeri ini. Unsur feodalisme tersebut terbawa hingga pada beberapa dekade selanjutnya. Pada era tahun 1970-an, misalnya, karya berbau feodalisme tetap hadir, antara lain, seperti karya RAF berjudul "Pipisahan" berikut. Novel yang ditulis dalam bahasa Sunda tersebut berbicara tentang feodalisme yang diterapkan ke dalam lingkungan sebuah keluarga. Novel tersebut membuktikan bahwa feodalisme dapat meruntuhkan keutuhan sebuah keluarga.

Keluarga merupakan unit dasar pengelompokan dan organisasi sosial dalam kehidupan bermasyarakat (Sariyun, 2006:40). Sariyun membandingkan lamanya interval tahapan yang harus dijalani kelompok keluarga manusia dengan kelompok keluarga makhluk lainnya, antara lain, hewan. Lamanya interval tersebut, menurut Sariyun, membuahkan ketergantungan dan kecenderungan pada pola tingkah laku yang diwariskan secara biologis. Dalam pandangan Sariyun, bentuk ketergantungan itulah yang kelak mendasari terwujudnya kebudayaan. Jelaslah budaya feodalisme yang disebarkan oleh orang tua dalam sebuah keluarga akan membawa dampak yang luar biasa, baik atau buruk, dalam kehidupan keluarga itu. Keluarga memiliki tiga fungsi utama, yaitu (1) melindungi dan mengarahkan (dalam arti mendidik) anak-anak sewaktu anak-anak itu secara fisik maupun sosial dalam keadaan tidak berdaya dan memiliki ketergantungan; (2) keluarga berfungsi sebagai pengendali kehidupan seks bagi laki-laki sebagai ayah; dan (3) keluarga sebagai pengatur pangan terutama dalam mendisiplinkan cara-cara makan kepada anak-anak (Sariyun, 2009: 40-41). Jika ketiga fungsi tersebut dilaksanakan sebuah keluarga ideal akan terwujud karena mampu menjalankan kewajibannya dan mengenali hak-hak yang diperlukan oleh anggota masing-masing. Keutuhan keluarga ideal tersebut dapat tereduksi dan berubah menjadi keluarga yang disfungsial.

\section{B. METODE PENELITIAN}

Feodalisme memerlukan pembahasan yang sangat luas. Namun, kajian ini dibatasi pada pengaruh feodalisme terhadap keluarga Sunda yang diwakili profil keluarga Sunda yang terdapat di dalam novel Pipisahan tersebut. Metode penelitian yang penulis gunakan adalah metode penelitian analisis deskriptif. Feodalisme difokuskan pada korpus yang mengusung aspek tersebut melalui tuturan dan perilaku tokoh Mama (panggilan Bapak dalam bahasa Sunda) kepada anak kandung dan menantunya. Korpus dalam novel Pipisahan adalah pada tuturan dan perilaku tokoh ayah mertua terhadap anak kandung dan menantunya sendiri serta 
pengaruh feodalisme pada kehidupan etnis Sunda dan keluarga Sunda. Untuk itu, kajian tentang feodalisme korpus tersebut dikaitkan dengan beberapa konsep berikut, yaitu konsep feodalisme Simorangkir, maskulinitas Reeser dan Connell, serta meme Dawkins. Tujuan dari kajian ini adalah sejauh mana pengaruh feodalisme dalam keluarga Sunda serta dampak apa yang ditimbulkan dari feodalisme itu terkait dengan unsur maskulinitas.

Feodalisme merupakan penguasaan suatu daerah di zaman pertengahan di Eropa (Shadily, 1986:998). Feodalisme timbul pada zaman kekuasaan raja-raja Frankia yang mengenal sistem vassal (adipati). Dalam sistem tersebut dikenal hubungan hukum antara golongan yang dipertuan dan para vassal. Di dalam hubungan hukum tersebut, pihak yang dipertuan memiliki kewajiban untuk memberikan perlindungan kepada para vassal. Sebaliknya, para vassal wajib mengabdi kepada tuannya, terutama bila timbul peperangan. Shadily juga menyampaikan bahwa feodalisme juga timbul dari sistem peminjaman tanah. Tuan tanah meminjamkan tanahnya kepada para vassal, tetapi hal itu menjadi ritual yang turun-temurun. Para vassal merasa berkuasa atas tanah itu dan meminjamkannya kepada golongan lain. Shadily menunjuk negara Jerman yang pernah terbagi menjadi beberapa wilayah raja kecil. Ia menegaskan bahwa feodalisme masih terdapat di beberapa tempat di dunia, terutama pada negara yang menganut sistem tuan tanah. Simorangkir menunjuk negara Afrika, Timur-Tengah, dan Amerika Selatan sebagai sebagai negara yang masih menganut feodalisme. Indonesia tidak luput dari feodalisme sebagai bukti interaksi negara itu dengan kaum penganut feodalisme pada masa lalu. Dalam Pada tahun 1800-an Indonesia mengalami berbagai persentuhan dengan kaum penjajah (Supriadi, et.al, 2010: 12-13). Batavsche Republiek berkuasa dari tahun 1799-1807 ${ }^{1}$, Koninkrijk Holland (1807-1810), Inggris (1811-1816), dan 1816 Belanda kembali berkuasa. Pada tahun itu, Belanda menerima kembali Indonesia dari tangan Inggris. Agenda Belanda selanjutnya adalah untuk mengeksploitasi tanah jajahan untuk menutupi kehancuran negara Belanda akibat peperangan. Agenda tersebut berjalan sangat rapi, di antaranya tanam paksa kopi (1830-1915). Di antara periode tersebut, pada tahun 1830, diberlakukan Undang-Undang Hak Tanah dengan bermunculannya perkebunan milik kaum kapitalis. Dengan undang-undang tersebut, Belanda kini mulai mengekspor hasil bumi tanah jajahannya. Namun, apa pun bentuk agenda tersebut, nasib rakyat tetap terabaikan. Kuli-kuli kontrak di perkebunan tidak lebih sebagai budak belian dengan beban kerja yang sangat besar sementara upah yang mereka terima sangat rendah.

Kehadiran feodalisme di negeri ini dapat dibuktikan dengan adanya perbedaan bentuk bahasa yang menunjukkan tingkat kedudukan pemakai bahasa dan berbagai tata cara dalam pergaulan kemasyarakatan. Feodalisme di negeri ini didukung kuat oleh kaum bangsawan yang dijadikan sebagai pilar kaum penjajah. Meskipun proklamasi sudah diproklamirkan, Indonesia tidak pernah terlepas dari feodalisme. Simorangkir menunjuk feodalisme yang tumbuh dan berkembang luas di kalangan birokrat. Tingginya kasus yang melibatkan aparat pemerintahan menjadi bukti masih tumbuh suburnya budaya feodalisme di negeri ini. Masyarakat cenderung menghormati dan mengagungkan aparat pemerintah yang sedang berkuasa.

Dikutip dari Kamus Besar Bahasa Indonesia berikut, makna feodalisme

\footnotetext{
${ }^{1}$ Periode 1799-1807 merupakan masa transisi kekuasaan asing di Nusantara akibat bubarnya Vereenigde Oostindische Compagnie (VOC). Pada saat itu Belanda dikuasai oleh Prancis dan nama pemerintahannya diganti menjadi Koninkrijk Holland.
} 
adalah sistem sosial atau politik yang memberikan kekuasaan yang besar kepada golongan bangsawan (Simorangkir, 2004: 43). Sistem sosial tersebut sangat mengagung-agungkan jabatan atau pangkat, bukan pada prestasi kerja (Simorangkir, 2004: 43-44) . Feodalisme di Barat, menurut Simorangkir, diawali dengan kepercayaan terhadap gereja Katolik dan Paus yang menjadi Kepala Gereja dipandang sebagai wakil Tuhan di atas dunia. Kedudukan raja semula berada di bawah Paus. Raja menuntut persamaan derajat. Ketidaksetujuan Paus menimbulkan konflik yang diakhiri dengan kemenangan raja. Kekuasaan Paus dibatasi pada urusan akhirat sementara urusan duniawi dikuasai oleh raja. Kedudukan raja semakin memperkuat feodalisme karena mendapat dukungan dari kaum ningrat. Rakyat dianggap sebagai pesuruh kaum bangsawan itu dan tidak memiliki hak suara. Ketidakadilan dalam sistem feodalisme tersebut mencapai puncaknya pada tahun 1789 ketika pecah revolusi Prancis. Banyak kaum bangsawan dan raja yang menjadi sasaran amukan rakyat dan direbut harta kekayaannya.

Akibat sistem feodalisme, yaitu (1) renggangnya hubungan persaudaraan, (2) manipulasi harga barang, (3) terciptanya iklim ekonomi yang tidak sehat, (4) semakin lebarnya jurang pemisah kelas manusia, antara si kaya dan si miskin, (5) sistem perbankan yang tidak sehat, (6) munculnya persaingan bebas, (7) aparat keamanan dan pemerintahan menunjukkan sikap pro kepada pengusaha, serta (8) maraknya peredaran narkoba dan korupsi (Simorangkir, 2004:54).

\section{Feodalisme dan Etnis Sunda}

Kehadiran kaum penjajah di negeri Indonesia juga banyak membawa dampak besar pada etnis-etnis yang terdapat di negeri itu, misalnya etnis Sunda. Kontak etnis Sunda dengan kaum penjajah (Belanda) dimulai pada tahun 1800-an melalui kontak antara para petinggi, seperti bupati, dengan para pegawai Belanda
(Supriadi et.al., 2010:12-13). Suratmenyurat menjadi aktivitas utama para petinggi daerah dengan petinggi Belanda. Kontak tersebut semakin intensif dan berlangsung turun-temurun melalui berbagai jenjang pendidikan, terutama bagi etnis Sunda yang mengenyam pendidikan di sekolah Belanda. Buah pendidikan tersebut, di antaranya terwujud dalam kehidupan etnis Sunda, salah satu di antarnya dalam bersastra. Tema-tema karya sastra yang dikelola oleh para menak juga mengangkat kehidupan di seitar lingkungan mereka. Supriadi et al. mengungkapkan bahwa sangat jarang karya sastra yang mengangkat tema tentang perlawanan rakyat jelata terhadap penjajah saat itu. Hal itu sangat dimungkinkan karena kaum bangsawan mendapatkan kemudahan dan keleluasaan dari pihak penjajah, di antaranya untuk mengenyam pendidikan. Selain itu, Pengaruh sastra Eropa dengan leluasa menyelusup karya-karya sastra yang muncul saat itu.

\section{Feodalisme dan Meme}

Dalam "Meme dalam Tiga Cerpen", Nurfaidah mengupas tentang fenomena Ponari dengan batu langitnya dan Ustadz Haryono dengan "kemampuannya" memindahkan penyakit dari pasien manusia ke badan hewan lain, seperti domba atau ayam. Kehadiran kedua tokoh tersebut mengundang atensi massa yang luar biasa. Fenomena di dunia kesehatan tersebut muncul karena bermula dari sebuah keyakinan dalam diri seseorang. Dilatarbelakangi perbedaan kondisi perekonomian serta ketidakadilan pada rakyat (Grehenson: 2010 dan Lakoni: 2010), seseorang berupaya memeras otak dan melakukan 'ikhtiar' untuk mendapatkan penanganan kesehatan yang dianggap murah dan mudah. Keyakinan tersebut berasal dari salah satu unsur pembentuk individu manusia, yaitu meme. Meme terkadang disebandingkan dengan gen, salah satu unsur pembentuk individu lain yang berfungsi menurunkan sifat 
generatif. "gen" merupakan satuan transmisi genetis yang diwariskan dari generasi ke generasi dengan peluang mutasi yang secara akumulatif dipahami sebagai evolusi sementara meme merupakan satuan transmisi kebudayaan (Wijayanto, 2012:xiii). Meme adalah unit kebudayaan yang dapat dipindahkan, dikomunikasikan, digandakan, dan diwariskan (Dawskin dalam Wijayanto, 2012:9). Berbeda dengan gen yang memperbanyak dirinya dengan cara melompat dari tubuh ke tubuh lainnya melalui reproduksi, meme memperbanyak dirinya dalam kolam meme dengan cara melompat dari otak ke otak lainnya melalui cara imitasi (dalam arti luas). Jika gen diturunkan secara vertikal dari generasi ke generasi, meme selain dapat diturunkan secara vertikal juga dapat disebarkan secara horizontal. Salah satu contoh penyebaran gen adalah melalui DNA antargenerasi. Tidak mengherankan jika di dalam realitas sering ditemui $\mathrm{Si}$ A mirip dengan ayahnya atau ibunya, Si B mirip dengan Ayah dan ibunya, atau Si A mirip kakek atau neneknya. Pada kasus lain, Si A mewarisi penyakit degeneratif dari pihak ayah, ibu, kakek, atau neneknya. Sementara itu, salah satu contoh penyebaran meme adalah fenomena Ponari tadi. Bermula dari ketidaksengajaan anak itu saat menemukan batu yang tersambar petir dan kesembuhan seseorang dari penyakit yang dideritanya. Pasien tersebut menyampaikan berita kesembuhannya melalui cara dari mulut ke mulut. Berita kesembuhan itu bukan hanya didengar oleh satu orang melainkan sampai ribuan orang. Antrian sesak di lokasi penyembuhan yang dilakukan oleh Ponari terjadi karena penyebaran meme, baik secara vertikal (dari satu generasi ke generasi lain) maupun horizontal (dari satu kepala ke kepala yang lain). Penyebaran meme tersebut turut melibatkan salah satu unsur unik dalam diri manusia, yaitu kesadaran. Manusia memiliki insting dasar untuk bertahan hidup. Kesadaran untuk bertahan hidup itulah yang membawa manusia untuk beradaptasi dan berjuang. Pada kasus Ponari, bermula dari kesembuhan yang tidak disengaja, pasien tersebut 'menyadari' bahwa dengan melakukan terapi batu langit itu ia dapat bertahan hidup. Kesadaran tersebut membawa si pasien pada beberapa keyakinan berikut, yaitu (1) anak yang ia temui bukan anak sembarangan atau ajaib, (2) batu yang dipegang si anak bukan batu biasa, (3) kesembuhan dari sebuah penyakit, (4) animo untuk menyampaikan berita kesembuhan. Meme pada pasien tersebut berupa sebuah keyakinan bahwa Ponari benar-benar seorang dukun cilik ajaib menyebar dari satu kepala ke kepala yang lain, dari satu wilayah ke wilayah yang lain.

\section{Feodalisme dan Maskulinitas}

Christ mengatakan bahwa dalam semesta ini terdapat dualisme yang mutlak, yaitu feminitas dan maskulinitas. Christ memandang femininitas sebagai sisi yang memberlakukan unsur melahirkan, merawat, menjaga, pasif, menenangkan dan mendamaikan tampil lebih dominan daripada unsur sebaliknya yakni maskulinitas. Maskulinitas adalah sisi lain dari koin semesta ini di unsurnya didominasi oleh hadirnya kekuatan, perubahan, penghancuran, aktif dan dinamis. Keduanya saling bertentangan namun sekaligus merupakan kesatuan semesta yang sifatnya alamiah. Dari kedua pandangan tersebut, Christ mengibaratkan dualisme semesta itu sebagai yin dan yang untuk menciptakan keseimbangan dunia dan kosmik. Christ memandang kedua hal itu mutlak ada di dunia jika tidak menginginkan kemandegan maupun sebaliknya, kehancuran bagi semesta kita ini.

Dualisme semesta itu sejatinya dapat berjalan seiring, tetapi dalam realitas hal itu tidak demikian. Tidak jarang terjadi konflik di antara dua sisi femininitas dan maskulinitas. Femininitas dan maskulinitas merupakan bentukan budaya. Konsep kedua hal itu akan berbeda pada setiap budaya. Hal itulah yang membuat 
persoalan tentang femininitas dan maskulinitas seakan tidak pernah usai. Makalah ini akan menempatkan feodalisme yang mengarah pada maskulinitas. Reeser, dalam Pratiwi, juga mengungkapkan bahwa perbedaan budaya akan membentuk variasi konsep maskulinitas dan nilai budaya terhadap maskulinitas. Ia mengatakan bahwa maskulinitas dikonstruksi oleh ideologi, dominasi, praktik, bahasa, dan elemen lain yang berhubungan. Pratiwi juga mengungkapkan pendapat Connell tentang maskulinitas. Connell menyatakan bahwa keragaman budaya dan konsep maskulinitas menimbulkan kompleksitas tersendiri sehingga standar normatif maskunitas sulit dipenuhi kaum laki-laki di seluruh dunia. Connell lebih lanjut mengatakan bahwa konsep maskulinitas dibentuk oleh masyarakat untuk mengunggulkan patriarki dengan tidak mempertimbangkan dampak hal itu pada masyarakat sendiri. Pendapat Humm ditambahkan Pratiwi untuk memperkuat landasan penelitiannya, yaitu definisi tentang patriarki. Humm menyatakan bahwa patriarki merupakan suatu sistem otoritas laki-laki untuk menindas perempuan melalui institusi sosial, politik, dan ekonomi. Tanpa memedulikan latar historis suatu masyarakat patriarkis, baik feodal, kapitalis, maupun sosialis, Humm mendapati bahwa sebuah sistem berdasarkan gender dan jenis kelamin serta diskriminasi ekonomi beroperasi secara simultan. Dalam hal ini, berdasarkan pendapat Reeser dan Connell dalam Pratiwi tadi, saya mendapati kaitan antara feodalisme dan maskulinitas. Perjalanan sejarah feodalisme selalu menguntungkan pihak laki-laki. Dalam berbagai hal kebijakan kekuasaan, feodalisme menempatkan perempuan sekadar sebagai objek. Kehadiran perbudakan, dogma domestikasi perempuan, jugun ianfu, dan berbagai wujud penyingkiran peranan perempuan selalu hadir silih berganti pada setiap waktu seiring sulit luruhnya feodalisme dari kehidupan manusia.

\section{HASIL DAN BAHASAN}

Pembahasan tentang feodalisme dalam novel Pipisahan karya RAF tersebut terdiri atas ringkasan cerita, feodalisme dalam Pipisahan karya RAF, feodalisme dan meme dalam Pipisahan karya RAF, serta feodalisme dan maskulinitas dalam Pipisahan karya RAF. Ringkasan cerita memaparkan sekilas cerita yang terdapat dalam novel Pipisahan. Sementara itu, pembahasan atau hasil analisis merupakan telaah kritis atas feodalisme yang terdapat dalam novel Pipisahan karya RAF berdasarkan pada beberapa landasan teori yang dipaparkan pada bagian awal artikel ini. Setelah mengetahui feodalisme yang terdapat di dalam novel tersebut, analisis dilakukan pada aspek penyebaran feodalisme yang dikaitkan dengan meme serta aspek maskulinitas dalam sistem itu.

\section{Ringkasan Cerita}

Novel Pipisahan bercerita tentang kandasnya pernikahan tokoh Emin dan suaminya. Perkawinan berbuah tiga anak lelaki yang lucu tersebut dihancurkan. Pemicu kehancuran perkawinan mereka adalah campur tangan mertua Emin yang menancapkan kukunya dalam-dalam ke dasar bahtera itu. Emin dipaksa mertuanya untuk melepas suaminya demi seorang perempuan bernama Eja yang 'dijagokan' mertuanya sebagai 'istri ideal' bagi suaminya. Meskipun pedih, Emin tidak dapat menentang kekuasaan sang mertua dan memilih untuk kembali ke kampung halamannya. Bersama si bungsu, ia meniti hidup sebagai orang tua tunggal. Belakangan anak kedua menyusul karena tidak dapat berjauhan dengan ibunya. Hanya si sulung yang tinggal bersama ayahnya. Sebagai istri kedua, Eja digambarkan memiliki rasa malu yang tiada tara kepada Emin karena ia menempati posisi mantan istri suaminya itu dengan cara yang tidak lazim. Eja tidak mengetahui bahwa lelaki yang dijodohkan kepadanya sudah beristri dan perempuan itu terpaksa mengalah demi dirinya. 
Penyesalan Eja tertuang dalam sebuah surat pengantar ketika pengasuh anak tirinya mengantarkan anak kedua ke kampung halaman.

Tidak lama, tersiar kabar bahwa mantan suami Emin menderita sakit berat. Emin dan kedua anaknya terpaksa tinggal semalam di rumahnya dulu dan turut merawat mantan suaminya. Tidak lama setelah kunjungan Emin dan kedua anaknya itu, mantan suami Emin meninggal dunia. Sepeninggal mantan suaminya, mantan mertua Emin masih menunjukkan kekuasaan dan ketamakannya. Ia merampas hampir semua barang peninggalan mantan suaminya itu. Akhir cerita, Eja—yang ternyata sedang berbadan dua-memutuskan untuk kembali ke kampung halamannya dan berencana melahirkan anaknya di tempat itu. Sementara itu, Emin dan ketiga anaknya kembali ke kampung halamannya. Cerita miris tentang sebuah perkawinan itu dipaparkan dari sudut pandang tokoh Emin sebagai kuring (aku).

\section{Feodalisme dalam Pipisahan Karya RAF}

Latar novel Pipisahan adalah era berkembangnya sistem feodalisme atau pada masa pemerintahan Belanda, sekitar paruh kedua abad ke-19. Prakiraan latar waktu tersebut terdapat secara simbolik dalam kutipan berikut.

Cara basa bulan katukang. Basa kuring gok panggih jeung urut batur salaki baréto. Basa salaki kuring jadi juru tulis Camat, manéhna cenah digawé di SS.

Seperti yang terjadi sebulan yang lalu. Saat itu aku bertemu dengan seorang teman lama suamiku. Saat itu suamiku bekerja sebagai seorang juru tulis di kantor kecamatan, orang itu mengaku bekerja di SS. (RAF, 2012:70)

SS dalam kutipan tersebut merupakan singkatan dari Staats Spoorwegen (Jawatan Kereta Api Milik Negara). Dalam situs resmi Dinas Perhubungan, komunikasi, dan Informatika Daerah Istimewa Yogyakarta (Diskominfo DIY) ${ }^{2}$, SS didirikan pada 1870-an oleh Belanda untuk membuka jalur transportasi BataviaBogor. Pada saat itu, pengaruh Belanda sedang menguat terutama di kalangan kaum bangsawan. Diskriminasi antara kalangan berdarah biru dan rakyat jelata sangat kuat. Pembedaan tersebut sangat jelas terlihat melalui pembakuan berbagai gelar kebangsawanan, seperti Raden ${ }^{3}$. Sepeninggal mantan suaminya, tokoh Emin mendapatkan gelar Nyi Raden dari mantan bapak mertua, Mama Sukarna, yang dulu sangat membencinya. Selain itu, masih ada gelar lain yang disebutkan dalam cerita, yaitu Dang (RAF, 2012:5859). Dang adalah singkatan dari Adang atau Dangdayang, gelar untuk keluarga kerajaan atau penghuni istana ${ }^{4}$.

Tamu téh dicalikkeun di tepas. Ema téh teu kersa mayunan, pajarkeun téh isin saurna. Putra Juragan CamatDang Ilin jeung Dang Empénnyampeurkeun budak kuring nu keur nyoo galatikna.

Tamu dipersilakan duduk di ruang depan. Emak enggan menghadapi mereka. Malu, katanya. Sementara anak Juragan Camat-Dang Ilin dan Dang Empén menghampiri anakku yang sedang asyik bermain dengan burung gelatik peliharaannya (RAF, 2012:58).

Warga bumi pertiwi yang bekerja sebagai ambtenaar atau pegawai negeri di beberapa perusahaan milik Belanda dianggap sebagai petinggi dan menempati kedudukan setara dengan kaum priyayi. Kedudukan mereka sangat istimewa, terlebih dengan adanya sebutan-sebutan

2 "Sejarah Kereta Api", diunduh dari http://www.dishub-diy.net/sejarah-

transportasi/sejarah-kereta-api.html, tanggal 21 Juni 2013, pukul 14.02 WIB.

3 Sampai saat ini, gelar tersebut masih digunakan sebagian kalangan masyarakat Sunda yang masih mengagunggkan feodalisme.

4 Danadibrata. R.A. 2006. Kamus Basa Sunda. Bandung: Kiblat Buku Utama, hlm. 158. 
sesuai dengan jenis pekerjaan yang mereka (atau suami mereka) tekuni, misalnya Nyi Guru, Nyi Mantri Guru, dan Jang Guru bagi mereka yang berprofesi sebagai guru. Tokoh kuring atau Emin mendapatkan julukan sebagai Nyi Ulis karena bersuamikan sebagai seorang Juru Tulis di sebuah kantor kecamatan, meskipun ia sudah bercerai dengan suaminya (RAF, 2012:59). Tokoh lain yang tidak disebutkan perananannya di dalam cerita juga mendapatkan gelar Nyi Komis Pos karena suaminya menempati jabatan paling rendah di kantor pos (RAF, 2012:59). Selain dengan sebutan Nyi, seorang istri petinggi juga terkadang disebut Juragan yang diikuti dengan kedudukan suaminya serta kedudukan dia disamping suaminya, seperti Juragan Camat Istri, Bendara Wadana Istri, serta Juragan Wadana Istri (RAF, 2012:58-59). Adapula pegawai bank yang disebut Juragan Agén Bang (RAF, 2012:77). Contoh sebutan tadi terdapat dalam kutipan berikut.

"Éta kamari, aya tamu ti Kabupatén. Mani bingung nyayagikeun tuangna, da Nyi Ulis di dieu budak kénéh can teurangeun kana ata-utuna nyayagikeun tuangeun, Nyi Mantri Guru deuih keur kabeneran teu aya, béjana mah keur ngalongok putrana ngalahirkeun. Ari Aceuk... atuh abdi katamak-kutumuk sorangan. Kadua Nyi Komis Pos, dibantuan ku barudak. Terang-terang aya Aceuk di dieu mah, na hésé-hésé teuing. Bro baé ka Aceuk ${ }^{5}$ nu tos biasa".

"Kemarin datang tamu dari Kabupaten. Saya sangat kebingungan menyediakan hidangan untuk mereka. Nyi Ulis yang ada di sini masih tergolong anak-anak, dia belum mengerti bagaimana cara menyiapkan hidangan untuk tamu terhormat. Nyi Mantri Guru kebetulan sedang pergi menjenguk anaknya yang baru melahirkan. Akibatnya, mau tidak

\footnotetext{
${ }^{5}$ Panggilan kepada kakak perempuan atau perempuan yang dianggap sebagai kakak.
}

mau saya harus sibuk sendiri, dibantu Nyi Komis Pos dan juga anak-anak. Andai saya tahu Aceuk ada di sini, pasti kami tidak akan mengalami kesulitan. Urusan menghidangkan makanan pasti akan saya serahkan sepenuhnya kepada Aceuk karena Aceuk sudah biasa menangani hal itu". (RAF, 2012:59)

Selain melalui penamaan, feodalisme juga tertanam dalam cara pandang. Hal ini tertuju pada sikap yang ditunjukkan hampir setiap tokoh yang ada di dalam cerita jika bertemu dengan orang yang berkedudukan lebih tinggi. Penghormatan pun seolah diwajibkan bagi orang yang berkedudukan lebih rendah. Tokoh Emin tidak dapat menolak permintaan seorang istri petinggi untuk membuatkan baju seragam bagi anak-anaknya menjelang sebuah perhelatan. Selain itu, tokoh Emin tidak mampu menolak kehendak bapak mertuanya jika lelaki itu sudah memiliki satu keinginan. Suami tokoh Emin pun demikian. keinginan Bapak Mertua Emin selalu dipenuhi.

Cara pandang feodalisme lain juga ditunjukkan oleh tokoh Mama Sukarna terhadap Emin dan suaminya. Mama Sukarna menempatkan anak lelakinya sebagai sapi perahan. Jerih payahnya membesarkan anak lelakinya itu (peranan istri Mama Sukarna tidak pernah disebutkan dalam cerita) dianggap sebagai jalan untuk menuai hasil. Mama Sukarna menempatkan kebanggaan yang tinggi kepada anak lelakinya itu. Namun, kebanggaannya itu menempatkan kedudukan dirinya lebih tinggi daripada si anak. Dengan demikian, si anak wajib memberikan penghormatan yang sangat tinggi kepada dirinya sebagai pahlawan yang memperjuangkan keberhasilan anaknya itu. Mama Sukarna berkali-kali mengintimidasi Emin dan suaminya demi pemenuhan kepentingan dan kebutuhan pribadinya dengan tidak melihat kondisi dan situasi anak dan menantunya itu.

Pada suatu waktu, Mama Sukarna menyatakan maksud kedatangannya 
kepada Emin dan suaminya. Ia mengatakan ingin meminjam uang dalam nominal tertentu karena akan memenuhi satu hal. Anak dan menantu Mama Sukarna terbelalak ketika lelaki sepuh itu menyampaikan jumlah nominal yang dibutuhkan. Angka yang disebutkan oleh Mama Sukarna sangat tidak memungkinkan untuk dipenuhi anak dan menantunya itu, sekalipun mereka harus menjual sawah dan menambahinya dengan uang tabungan mereka. Mama Sukarna mendadak berang ketika anak dan menantunya meminta kejelasan lebih lanjut tentang pinjaman itu. Akal sehat Mama Sukarna seperti menghilang. Ia berburuk sangka kepada keduanya, terutama kepada menantunya. Ia mengatakan bahwa kini sikap anaknya sudah berubah karena dianggap Mama Sukarna sang anak lebih mengutamakan kepentingan istrinya daripada orang tuanya. Sikap Mama Sukarna yang hegemonik tersebut memaksa anak dan menantunya melepas harta mereka satu-satunya yang dibelinya dengan susah payah. Demi ambisi Mama Sukarna mereka terpaksa menggadaikan sawah itu. Uang hasil penggadaian sawah itu tidak tahu rimbanya. Hasil dari 'peminjaman' aset anak dan menantu itu lenyap tidak berbekas. Kekesalan Emin sebagai menantu tergambarkan dalam kutipan berikut.

Ari ayeuna. Teu gugur teu angin ... kudu dikaluarkeun deui, keur nyumponan kapalay Mama nu teu bisa dipondah. Enya, ari enyana mah harita téh ngan ukur digadékeun. Tapi da sanajan salaki kuring ngagedékeun hate, ti harita gé kuring mah yakin, yén pamohalan bisa dipimilik deui.

Moal ... moal katebus deui. Komo ieu gedé, kapan nu jumlahna laleutik ogé nu enggeus-enggeus, teu puguh hulu buntutna.

Sekarang... tidak disangka-sangka... sawah itu harus dilepaskan lagi demi memenuhi kehendak Mama yang tidak tertahankan. Memang, sih, sawah tersebut saat itu hanya digadaikan. Namun, meskipun suamiku senantiasa membesarkan hati untuk bersikap optimis, hati kecilku berkeyakinan bahwa sawah itu tidak akan pernah menjadi milik kami lagi.

Tidak ... pasti tidak akan bisa ditebus lagi. Apalagi untuk yang besar, pinjaman 'kecil' yang sering Mama lakukan dari kami, tidak pernah berujung pangkal atau membuahkan hasil. (RAF, 2012:56)

Berkali-kali Mama mengintimidasi perekonomian anak dan menantunya. Pinjaman demi pinjaman yang dilakukan Mama tidak pernah membuahkan hasil. Hasil jerih payah anaknya hilang begitu saja dalam genggaman ayahnya sendiri.

Sikap Mama tidak pernah berubah ketika sang anak berada dalam kondisi yang sangat tidak memungkinkan untuk dipinjami. Hati nurani seorang ayah tertutup rapat ketika ia dengan keji mengambil jatah susu anaknya sendiri yang didera sakit parah. Seorang petinggi sebelumnya memberikan tiga kaleng susu ketika ia menjenguk sang juru tulis (mantan suami Emin). Susu tersebut sangat diperlukan untuk pemulihan anak lelaki kebanggaannya. Namun, Mama Sukarna dengan keji mengambil dua kaleng susu dan menyisakan satu kaleng saja untuk anaknya sendiri.

"Geuning atuh teu aya susu keur ngaleueutna? Téténjoan Aceuk mah ngan aya cai téh jeung cai hérang."

"Cihérang ti Mama éta téh mangkuna. Saurna cai du'a," jawabna. "Kamari mah aya susu cisusu mung wengi nyéépkeun. Éta ogé aya sotenan susu dikintun $k u$ Juragan Sékertaris minggu pengker tilu blék, naming kamarina basa Mama ka dieu dicandak dua blék. Saurna, geus lami teu ngeleueut susu."

"Har, kapan keur nu gering?" cek kuring.

"Nu mawi duka kumaha abdi téh. Teu wanton ari nyebatkeun itu mah. Sok 
gampil bendu upami aya kapalay teu katedunan téh."

"Lho, kok, nggak disediakan susu?

Yang Aceuk lihat hanya ada air teh dan air putih."

"Air putih itu dari Mama kemarin. Kata Beliau, itu air doa," jawabnya. "Kemarin masih ada air susu. Penghabisan. Itu pun kiriman dari Juragan Sekretaris minggu lalu, sebenarnya sebanyak tiga kaleng, tetapi Mama mengambilnya sebanyak dua kaleng. Alasan Mama, sudah lama beliau tidak minum susu.

"Apa? Bukankah kiriman itu untuk yang sakit?" tanyaku.

"Entahlah, saya tidak mampu membantah Mama. Saya tidak berani menyampaikan hal itu. Mama akan mudah tersinggung jika keinginannya tidak dipenuhi." (RAF, 2012:85)

Eja mengalami hal yang sama seperti yang pernah dialami oleh Emin, yaitu tidak mampu menolak derasnya ambisi mertua. Emin dengan sukarela mengeluarkan uang belanja untuk menutup keperluan dapur madunya itu. Kondisi sangat memprihatinkan harus dialami Eja dan suaminya. Kebutuhan pasien nyaris tidak terpenuhi jika Emin tidak segera mengatasi hal itu. Lagi-lagi, Mama Sukarna menjadi biang keladi kesulitan dan keterpurukan bahtera anaknya. Terlebih lagi posisi Eja sebagai perempuan pillihan yang sengaja 'ditahbiskan' Mama Sukarna demi menggeser kedudukan Emin. Eja tidak memiliki hak untuk membela kepentingan rumah tangganya sendiri ketika ambisi Mama Sukarna menyerang mereka. Penunjukkan Eja sebagai pendamping anak lelakinya setelah kepergian Emin menunjukan bahwa perempuan kedua itu harus bersikap 'lebih baik' daripada perempuan pertama dalam melayani ambisi mertuanya.

Hati nurani Mama Sukarna tidak juga terkuak ketika ia baru saja kehilangan anak lelakinya yang harus meregang nyawa karena penyakit yang tidak pernah terdiagnosis jenisnya itu. Kesedihan seolah terusir sangat jauh pada saat rembukan pelaksanaan tahlil dilaksanakan. Mama Sukarna menancapkan kukunya dalamdalam pada beberapa benda yang diwariskan mendiang anaknya. Ia menginginkan sejumlah benda yang ada di rumah itu, termasuk hampir seluruh pakaian peninggalan mendiang.

"Titingalan mah titingal nu maot téh teu sabaraha. Pakéanana aya dua koper. Mun rujuk mah, éta pakéan rék dibantun, keur pangéling-éling. Rék jeung koperna baé sakalian dan hésé mawana."

Taya kénéh nu mairan, jempé saréréa ogé.

“Éja, lomari nu di jero kamar téa ku Mama rék dibawa, butuh keur teuteundeunan. Jeung mun Éja rido mah, bupét nu di tengah imah deuih nu rék dibawa téh." (Boh lomari, boh bupét éta meunang meulian jeung kuring baréto).

[...]

Isukna nganggo sinjang Cap Padi beureum, raksukan tutup saput kayu weuteuh kénéh, bendo citak (kabéh oge nu almarhum-cek Éja, baju tutupna mah can kungsi dianggo, barang jol ti tukang ngaput kaburu brek teu damang), Mama Sukarna mulih.

Nyandak koperna ogé tilu.

"Kalau saya lihat, peninggalan mendiang tidak seberapa. Bajunya hanya dua koper. Seandainya kalian setuju, saya akan membawanya ke kampung sebagai kenang-kenangan, sekalian dengan kopornya. Tanpa kopor, saya susah membawa bajubaju itu.

Tidak ada yang membantah, semua berdiam diri.

"Eja, lemari yang ada di dalam kamar akan saya bawa, perlu untuk tempat menyimpan barang. Oh, ya, kalau Eja rido, bufet yang di tengah rumah juga (Padahal, lemari atau buffet itu kami yang membelinya kata Emin dalam hati)." 
[...]

Keesokan harinya, sambil mengenakan sarung Cap Padi berwarna merah, baju luar warna cokelat kayu yang masih baru, dan tutup kepala (semua milik mendiang mantan suaminya-Eja mengatakan bahwa baju luar itu tidak sempat dipakai oleh mendiang setelah selesai dijahit karena sakit), Mama Sukarna pergi lengkap dengan tiga buah kopor. (RAF, 2012: 97-100)

Namun, puncak dari kekejian Mama Sukarna adalah menghancurkan bahtera anak kandungnya sendiri. Emin dipaksa berpisah dengan suami yang sangat ia cintai dan salah seorang dari ketiga anaknya. Selain dipaksa memutuskan cintanya di tengah jalan, Emin juga dipaksa untuk menerima kenyataan bahwa posisinya sudah digantikan oleh seorang perempuan pilihan sang mertua. Perempuan yang dalam penilaian, baik Emin maupun Mama Sukarna, menjadi perempuan yang lebih baik dalam segala hal. Eja dengan polos menerima tawaran itu. Ketika akhirnya ia mengetahui hal itu, Eja dengan penuh penyesalan menyampaikan permintaan maafnya kepada Emin. Emin pun bersikap baik kepada madunya itu. Satu alasan Emin mengalah kepada bapak mertuanya itu adalah untuk membuktikan bahwa suaminya dapat lebih mengutamakan kepentingan sang mertua daripada pasangan hidupnya. Hal itulah yang menjadi senjata bagi Mama Sukarna untuk menyingkirkan menantu perempuannya itu, Emin, ia dianggap sebagai penghalang pemenuhan kebutuhan hidupnya. Hanya karena anak dan menantunya mempertanyakan alasan peminjaman uang dalam jumlah besar, meskipun disampaikan dengan bahasa yang sangat halus, Mama Sukarna tersulut emosinya dan menyampaikan dengan bahasa yang menyakitkan.

"Sakali deui daréngékeun. Mama téh lain rék ménta. Teu atuh ka manéhna (sasauranana ka salaki kuring) teu deuk punta-pénta. Moal ... moal ménta pamulang tarima. Da puguh ari geus kieu mah, leuwih penting bojo batan kolot sorangan. Kitu puguh ge dunya mah. Ngan alusna mah Eminna baé (ka kuring ayeuna mah), sing bisa ngaragap kana haté salaki. Da ari salaki mah meureun hayangeun bisa nulungan ka nu jadi bapana. Yeuh, Min, sing inget, nginjeum Mama mah ... nginjeum!”

Kuring olohok mata simeuteun. Teu sangka ku bakal kitu kasauranana.

"Har, na da abdi mah teu naon-naon. Mung nu janten bingung téh, ku nuju teu ayana. Komo seueur-seueur kitu..."

"Ngarti," Mama megat kalimah gancang naker. "Ngarti Mama gé, sarta geus ditungguan tangtu kitu kecap hidep gé. Ngan nu pangpentingna keur Mama mah ayeuna, lain soal ayana dina pésak, tapi niatna. Da mun aya niat mah lain soal nu hésé..."

"Sekali lagi kalian dengarkan bahwa Mama bukan ingin meminta. Tidak kepada dia (bicara ke arah suamiku) untuk meminta. Tidak .... Mama tidak bermaksud meminta balas budi. Ya, memang dalam kondisi seperti ini (kawin), kepentingan istri lebih penting daripada kepentingan orang tua sendiri. Dunia memang seperti itu. Hanya saja, Emin (sambil mengarah kepadaku) sebagai seorang istri harus bisa membaca hati suaminya. Siapa tahu suamimu memang sebetulnya bersedia menolong ayah kandungnya sendiri. Eh, Emin, ingat... Mama hanya meninjam uang.... Sekali lagi pinjam."

Aku tercengang mendengar kata-kata bapak mertuaku. 
"Maaf, Mama, bagi saya tidak mengapa. Tapi kami sedang tidak punya uang. Apalagi dalam jumlah yang besar seperti itu."

Mama memotong kalimatku secepat kilat, "Aku mengerti. Seperti yang sudah kuduga sebelumnya, jawaban itu yang pasti akan kudengar. Yang paling penting bukan jumlah uang yang ada di dalam kantong, tapi niatnya. Kalau soal niat bukan perkara yang susah..." (RAF, 2012: 55)

Feodalisme dalam setiap kalimat yang diucapkan oleh Mama tampak mengandung unsur sinistik. Ucapan Mama dapat dikatakan mengandung laknat bagi sang menantu yang dianggapnya sebagai orang yang menumpang hidup pada kesuksesan suaminya. Emin dianggap Mama Sukarna sebagai seorang rakyat jelata yang tidak memiliki hak suara, tetapi dengan lancang menghalangi niat suaminya untuk menolong ayah kandungnya sendiri (bapak mertua Emin). Mama Sukarna tidak dapat membaca bahwa anaknya sendiri terjerat dalam dilema karena kondisi keuangan mereka memang tidak memungkinkan untuk memberikan pinjaman. Pinjaman terakhir tersebut jumlahnya merupakan yang terbesar dari serangkaian pinjaman lain yang tidak pernah kembali dan tidak pernah terlihat jelas hasilnya. Untuk memenuhi ambisi bapak mertuanya itu, seringkali Emin terpaksa menjual barang berharga miliknya (hlm. 54). Bagi seorang Mama Sukarna, keberhasilan anaknya adalah memiliki karir yang gemilang. Namun, hal itu harus diikuti dengan kemampuan si anak memberikan upah kepada orang yang kedudukannya lebih tinggi (orang tua) yang sudah memfasilitasi si anak ke jenjang keberhasilan itu.

Sikap Mama Sukarna itu merupakan cerminan sikap kaum penjajah yang dengan lebar memberikan keleluasaan bagi kaum bangsawan untuk menikmati jenjang pendidikan ala Eropa dan menikmati kekuasaan yang membuatnya berbeda dengan rakyat jelata. Namun, kaum penjajah tidak memberikan itu dengan cuma-cuma. Kaum bangsawan seolah dibaiat untuk berperan sebagai kepanjangan tangan penjajah di tengah kaumnya sendiri dan di negeri sendiri. Doktrin kewajiban menghormati orang tua disalahgunakan Mama Sukarna sebagai senjata baginya untuk mendulang keuntungan pribadi tanpa memedulikan akibat yang dialami oleh anak dan menantunya itu. Pandangan Mama Sukarna terhadap menantu merupakan cerminan politik devide et impera atau politik memecah belah ala Belanda. Sistem politik tersebut menimbulkan pengkotakkotakkan massa berdasarkan kedudukan, darah, dan kekuasaan. Menantu, bagi Mama Sukarna, adalah benalu yang dapat dengan sewenang-wenang disingkirkan dan digantikan posisinya dengan perempuan yang sama yang diharapkan 'dapat lebih mengerti' daripada yang terdahulu. Eja sebagai menantu terpilih mengalami nasib yang sama, seperti yang dialami oleh Emin. Kedudukan menantu di mata Mama Sukarna lebih rendah daripada seorang budak belian (anaknya sendiri). Jika sang anak dilarang untuk memiliki hak untuk membela diri, kondisi seorang menantu lebih parah. Kaum penjajah dengan semena-mena tega mengoyak kehidupan rakyat di tanah jajahannya. Hal itu juga diterapkan oleh Mana Sukarna kepada anak dan menantunya. Kebahagiaan sang anak tidak dibiarkannya berkembang dengan sendirinya, tetapi harus searah dengan kemauan Mama Sukarna. Jika tidak, Mama Sukarna akan bertindak dan menjatuhkan vonis yang cukup kejam, hukuman bercerai. Emin mengalami hal itu. Perceraian yang dengan terpaksa ia lakukan demi sebuah pembuktian bahwa anak lelaki kebanggaan Mama Sukarna adalah seorang anak yang lebih mementingkan kepentingan ayah kandungnya bukan istrinya.

$\mathrm{Nu}$ matak éta di antarana nu jadi sabab pang ahirna kapaksa kuring kudu balik ogé; kudu runtag rumah 
tangga téh saperti nu geus kacaritakeun. Di antarana mah nya pikeun ngabuktikeun téa baé, yén "henteu leuwih penting bojo, batan sepuh”. Ti anjeunna malah cék béja mah, calon keur gaganti kuring ogé songna téh.

Itulah salah satu di antara penyebab kepulanganku ke kampung halaman dan hancurnya rumah tanggaku, seperti yang pernah kuceritakan. Salah satu di antara tujuan perpisahan ini adalah pembuktian kepada bapak mertuaku bahwa anaknya 'sangat mengutamakan kepentingan ayah kandungnya daripada istrinya sendiri' Tersiar kabar bahwa beliau yang mendatangkan calon istri penggantiku. (RAF, 2012: 56)

Dari kasus yang menimpa Emin tadi, dapat dikatakan bahwa feodalisme mampu meluluhlantakkan fungsi keluarga menjadi sebuah disfungsi. Ketergantungan yang lama dari keturunan dalam sebuah perkawinan disalahgunakan Mama Sukarna sebagai sumber pemenuhan ambisinya sendiri. Ia tidak membiarkan si anak untuk mengembangkan atau memanjangkan hasil pembinaan dengan gayanya sendiri. Kemerdekaan anak kandungnya direngut begitu saja dan hanya dibolehkan bernafas selama dapat memenuhi kebutuhan sang ayah. Aspek pemenuhan pangan dalam sebuah keluarga juga menjadi disfungsial ketika keluarga inti menderita kekurangan dalam bidang ekonomi hanya karena dipaksa menyalurkan pendapatan keluarga kepada pihak lain yang dianggap lebih berkuasan. Keluarga Emin dan suaminya kerapkali dipaksa menghadapi kekuarangan karena simpanan keuangan mereka direngut oleh Mama Sukarna. Demikian pula yang terjadi kepada pasangan Eja dan suaminya (mantan suami Emin) ketika sakit. Mereka tidak dapat memenuhi kebutuhan pangan si sakit karena simpanan uang pasangan it, lagi-lagi direngut Mama Sukarna. Sementara itu, fungsi keluarga sebagai pengendali penyaluran hasrat seksual juga mengalami disfungsi karena pasangan suami-istri dipaksa memutuskan tali kasihnya. Jalinan cinta Emin dan suaminya dikendalikan oleh Mama Sukarna. Ketika dianggap tidak menyenangkan bagi Mama Sukarna, Emin dianggap tidak menyenangkan juga bagi suaminya. Kekuasaan Mama Sukarna yang otoriter tersebut menjatuhkan vonis kejam bagi tokoh Emin.

\section{Feodalisme Sebagai Meme dalam Pipisahan Karya RAF}

Sejak kemunculannya feodalisme tergolong mendulang sukses dalam hal pemertahanannya. Feodalisme merupakan bentukan budaya, yaitu budaya imperialisme. Sama halnya dengan meme, feodalisme memiliki dua cara untuk bereduplikasi, yaitu horizontal dan vertikal. Kedua cara itu membuahkan hasil yang memuaskan. Reduplikasi feodalisme secara horizontal terjadi karena kontak si pembawa paham feodal dengan orangorang yang bersepaham dan dapat menerima paham itu. Hal itu terjadi dalam bentuk penaklukan dan kebutuhan sang penjajah untuk memanjangkan dan memperkuat kekuasaannya di tanah jajahan. Kontak antara kaum penjajah dan kaum bangsawan yang tidak terkait dengan darah merupakan reduplikasi secara horizontal. Reduplikasi tersebut terjadi berdasarkan perpindahan paham dari kepala yang satu ke kepala yang lain. Kaum bangsawan menerima kemudahan dalam berbagai hal yang diberikan oleh kaum penjajah sehingga dapat membuat mereka menempati posisi yang 'berbeda' daripada rakyat kebanyakan. Perbedaan itu membuahkan kenyamanan karena mereka dapat berlaku dengan semena-mena terhadap sesamanya hanya karena perbedaan latar pendidikan dan kedudukan sosial.

Sementara itu, reduplikasi feodalisme dapat terjadi secara vertikal. Reduplikasi tersebut terjadi antara generasi yang terikat hubungan darah. Orang tua yang berpaham 
feodalisme membakukan pola pendidikan berbasis feodal kepada anak-anak mereka. Sejak kecil anak-anak dilatih dengan perbedaan dan memandang perbedaan sosial dengan landasan bergaya feodal. Mereka dilatih untuk menjaga jarak dengan sesamanya dan melakukan tindakan 'tertentu' jika terjadi konflik dengan kalangan yang dibakukan tidak sederajat dengan mereka. Kasus-kasus penganiayaan, baik fisik maupun psikis, terhadap perempuan dalam rumah tangga atau terhadap para TKI, misalnya, yang bekerja di wilayah negara berbasis feodal merupakan salah satu bukti bahwa feodalisme masih ada. Tokoh Emin mengalami penganiayaan psikis dari Mama Sukarna, bapak mertuanya, hanya karena tidak mampu memenuhi ambisius lelaki itu. Demikian pula, hal yang sama dialami oleh tokoh juru tulis yang mengalami siksaan psikis dari ayahnya sendiri. Ia mendapatkan vonis keji dari ayahnya sendiri yang membuat dirinya terpisah jauh dengan pasangan hidup dan buah perkawinannya sendiri.

\section{Feodalisme dan Maskulinitas dalam Pipisahan Karya RAF}

Maskulinitas selalu memenangkan sosok maskulin terhadap sosok feminin. Feodalisme juga menunjukkan hal yang sama. Sistem itu menempatkan dampak yang cukup dahsyat, baik kepada kaum hawa maupun laki-laki. Feodalisme memunculkan kasus-kasus hegemonik yang tidak saja berlaku bagi kaum hawa maupun kaum adam. Hegemonik akan menyudutkan sosok perempuan ke dalam jurang kelemahan dan ketergantungan. Namun, hegemonic juga akan menyingkirkan sosok maskulin yang dianggap tidak dapat memenuhi ambisi maskulinitas pihak yang hegemonik itu.

Mama Sukarna menempati posisi hegemonik dalam samudera perkawinan anak lelakinya dan Emin. Mama Sukarna menempatkan dirinya sebagai penguasa lautan dan memandang bahtera perkawinan anak dan menantunya itu sebagai barang mainan yang bisa diatur dengan deburan ombak yang dikuasainya. Ia dengan sengaja melempar bahtera perkawinan itu ke mana saja arah yang ia kehendaki. Ketika permainan ombak yang dilakukannya menjadi radikal, hal itu membuahkan korban. Emin adalah korban pertama yang dijatuhkannya. Emin dianggap sebagai boneka yang dapat dipermainkan dengan sesuka hati. Dominasi maskulin Mama Sukarna dengan keji membuang boneka Emin ke dalam sebuah bak sampah dan menggantikan peranan boneka itu dengan sosok Eja. Dominasi yang sama dalam diri lelaki itu juga sudah mengoyak diri anak lelaki yang dibanggakannya itu. Ia tidak peduli akibat yang ditimbulkan dari perpisahan anak lelaki dan Emin akan berbuntut panjang. Ia tidak melihat penderitaan yang dialami oleh anak lelakinya adalah buntut dari penyesalannya terhadap perkawinannya dulu.

"Lamun téa mah, Akang kudu pondok umur, mihapé éja pangmentakeun dihampura ka Aceukna. Rumasa gedé dosa Engkang téh. Jeung béjakkeun mihapé barudak kituh. Percaya, yén dina leungeun indungna, barudak téh baris jaradi jelema."

Jika tidak berumur panjang, Eja, tolong sampaikan permintaan maaf Akang kepada Aceuk (Emin). Dosa Akang kepadanya tidak terukur. Tolong sampaikan juga Akang titip anak-anak. Akang percaya, di tangan ibunya, mereka akan jadi 'orang'."

(RAF, 2012: 102)

Sosok sang juru tulis digambarkan sebagai anak lelaki yang tidak memiliki hak suara terhadap ayah kandungnya. Ia tidak memiliki ruang yang cukup untuk membuktikan aspek maskulinitasnya sebagai seorang kepala rumah tangga.

\section{Penutup}

Feodalisme sejak pertama kemunculannya sampai saat ini tidak pernah punah. Meskipun sudah menapaki era modern, feodalisme masih dianut 
terutama oleh para penguasa, di antaranya, di negara-negara yang menganut sistem landlords. Feodalisme sangat didominasi oleh dampak negatif sistem sosial itu terhadap kehidupan manusia, di antaranya dalam lingkungan sebuah keluarga. Fungsi-fungsi keluarga dapat berubah menjadi disfungsial jika terkena dampak feodalisme. Feodalisme mengkotakkotakkan peranan sebuah anggota keluarga. Pihak-pihak di luar keluarga inti tidak membiarkan anggota keluarga itu untuk mengembangkan diri dan menemukan jati dirinya. Pihak-pihak tersebut ingin mengendalikan anggota keluarga inti agar bisa sejalan dengan mereka. Ketika anggota keluarga inti tidak dapat memenuhi keingingan pihak luar tersebut, ia tersingkirkan. Kasus yang menimpa anak lelaki Mama Sukarna merupakan salah satu cerminan kasus perpecahan keluarga berbasis feodalisme itu.

Dari paparan analisis tadi, didapati bahwa feodalisme dapat meruntuhkan ikatan keluarga serta melemahkan atau memusnahkan peranan anggota keluarga. Feodalisme merusak perekonomian keluarga dan fungsi-fungsi keluarga. Feodalisme dapat bertahan karena penyebarannya yang cukup unik, sebagai sebuah meme, yaitu penyebaran secara horizontal dan vertikal. Penyebaran feodalisme secara horizontal terjadi dari satu kepala ke kepala yang lain tanpa disertai dengan hubungan darah. Sementara itu, penyebaran meme secara vertikal terjadi dalam bentuk penanaman pemahaman feodalisme dalam lingkungan keluarga atau hubungan darah. Feodalisme adalah paham yang mengagungkan seseorang berdasarkan derajat atau kedudukan sosial, bukan pada prestasinya. Pengagungan tersebut disertai dengan penghormatan yang berlebihan. Hal itu memberikan dampak yang menguntungkan kepada pihak yang diagungkan dan kerugian kepada pihak yang mengagungkan. Keuntungan pada pihak yang diagungkan tersebut sulit dilepaskan karena ia tidak menginginkan kemudahan dan kekuasaan yang ada dalam genggaman. Sementara itu, bagi pengagung, ia tidak leluasa karena terikat pada sang penguasa. Feodalisme dapat mengakibatkan manusia terjerumus ke dalam kesewenang-wenangan sekaligus kesengsaraan.

Feodalisme tidak dapat dilepaskan dari aspek kekuasaan, kekerasan, dan kebahasaan. Feodalisme muncul dari kuasaan yang tidak seimbang, kekuasaan hampir tidak terbatas di pihak dominan dan ketidakberdayaan di pihak subordinat. Dalam kondisi demikian, tidak dapat dipungkiri terjadi kekerasan dalam berbagai wujud, baik kekerasan fisik maupun simbolik. Dalam novel Pipisahan terjadi kekerasan simbolik. Kekerasan simbolik tersebut berupa kekerasan verbal dan nonverbal. Kekerasan verbal terjadi ketika tokoh utama mendapatkan siksaan melalui kata-kata represif. Kekerasan nonverbal terjadi ketika sang tokoh mendapatkan perlakuan yang tidak menyakitkan dari orang yang dianggap memiliki kekuasaan dominan. Kekerasan simbolik tersebut disampaikan dengan bahasa yang mengusung makna dan maksud untuk menanamkan kuasa dominan pada pihak subordinat. Dengan demikian, Feodalilsme dapat dikatakan menjadi pemicu tumbuhnya marginalitas dalam kehidupan masyarakat.

\section{DAFTAR SUMBER}

\section{Makalah}

Nurfaidah, Resti. 2012.

"Meme dalam Tiga Cerpen", makalah dalam Seminar Internasional Pertemuan Ilmiah Bahasa dan Sastra Indonesia (PIBSI) XXXIV yang diselenggarakan oleh Prodi Bahasa dan Sastra Indonesia Fakultas Ilmu Sosial dan Ilmu Politik Universitas Jenderal Soedirman di Hotel Moro Seneng, Jalan Raya Baturaden, Purwokerto, 30-31 Oktober 2012.

\section{Buku}

Pratiwi, Fitria. 2012. 
"Rekonstruksi Maskulinitas dalam Tantri:

Perempuan yang Bercerita Karya Cok

Sawitri”. Tesis. Depok: FIB-UI.

RAF. 2012.

Pipisahan. Cetakan kedua. Bandung: Kiblat Buku Utama.

Rosidi, Ajip. 2009.

Manusia Sunda. Cetakan ketiga. Bandung: Kiblat Buku Utama.

Sariyun, Yugo. 2006.

"Kehidupan Keluarga Masyarakat Sunda" dalam Prosiding Konferensi Internasional Budaya Sunda, jilid kedua, halaman 40-49. Jakarta: Yayasan Kebudayaan Rancagé.

Shadily, Hasan. 1986.

Ensiklopedia Indonesia. Jakarta: Ichtiar Baru-van Hoeve.

Simorangkir, O.P. 2004.

Feodalisme, Demokrasi, dan Proses Reformasi Menuju Modernisasi. Jakarta: Tim Studi Pembudayaan Pancasila Universitas Krisnadwipayana.

Soewardi, Herman. 2006.

"Etos Kerja Orang Sunda" dalam Prosiding Konferensi Internasional Budaya Sunda, jilid kedua, halaman 8192. Jakarta: Yayasan Kebudayaan Rancagé.

Supriadi, Asep, Ayi Sofyan, Jujun Herlina, Nandang R. Pamungkas, dan Mohamad Asjar Rasjid. 2010.

"Dua Abad Sejarah Pertumbuhan dan Perkembangan Sastra Sunda di Jawa Barat: Sebuah Pendataan Awal". Laporan penelitian Tim. Bandung: Balai Bahasa Bandung.

Wijayanto, Eko. 2012.

Genetika Kebudayaan, Seri 2. Jakarta: Salemba Humanika.

3. Internet

Christ, Yoppie. 2011.

"Satu Pesan Tiga Peristiwa". Opini dalam http://sosbud.kompasiana.com/2011/04/25 /satu-pesan-tiga-peristiwa-357973.html diunduh tanggal 19 Juni 2013, pukul 12:04 WIB. 